\title{
Strength Analysis of an Aircraft Sandwich Structure with a Honeycomb Core: Theoretical and Experimental Approaches
}

\author{
Sadiq E. Sadiq (D) a*, Muhsin J. Jweeg (D) b, Sadeq H. Bakhy (D) c \\ ${ }^{a}$ Engineering Technical College of AL-Najaf, Al-Furat Al-Awsat Technical University (ATU), Iraq. \\ sadaiq.emad@atu.edu.iq \\ b Al-Farahidi University, Baghdad, Iraq. muhsin.jweeg@uoalfarahidi.edu.iq \\ ${ }^{c}$ University of Technology, Baghdad, Iraq.sadeqbakhy@yahoo.com \\ ${ }^{*}$ Corresponding author.
}

Submitted: $31 / 05 / 2020$

Accepted: 09/08/2020

Published: 25/01/2021

\section{K E Y W O R D S}

Sandwich beam,

Honeycomb core, static behavior, optimization and RSM

\begin{abstract}
A B S T R A C T
In this paper, the strength of aircraft sandwich structure with honeycomb core under bending load was evaluated theoretically and experimentally based on failure mode maps. A failure mode map for the loading under three-point bending was constructed theoretically to specify the failure modes and corresponding load. Three point bending test for aluminum honeycomb sandwich beam has been achieved to measure the peak load and maximum deflection. The obtained results elucidated a good agreement between the theoretical solutions and experimental tests, where the error ratio was not exceeded $12 \%$. The core height, the cell size and the cell wall thickness were selected to explore the effect of honeycomb parameters on the strength of sandwich structure. In order to obtain the optimum solution of peak load and maximum deflection and energy absorption, Response Surface Methodology (RSM) was used. Results showed that the maximum bending load, minimum deflection, and maximum energy absorption were found at $25 \mathrm{~mm}$ core height, $10 \mathrm{~mm}$ size cell and $1 \mathrm{~mm}$ cell wall thickness. The optimal value of maximum bending load, minimum deflection and maximum energy absorption were $1975.3415 \mathrm{~N}, 1.0402 \mathrm{~mm}$ and $1.0229 \mathrm{~J}$ respectively.
\end{abstract}

How to cite this article: S. E. Sadiq, M. J. Jweeg, and S. H. Bakhy, "Strength analysis of aircraft sandwich structure with a honeycomb core: Theoretical and Experimental Approaches," Engineering and Technology Journal, Vol. 39, Part A, No. 01, pp. 153-166, 2021. DOI: https://doi.org/10.30684/etj.v39i1A.1722

This is an open access article under the CC BY 4.0 license http://creativecommons.org/licenses/by/4.0

\section{INTRODUCTION}

Honeycomb core sandwich construction is usually utilized in structures, where the strength, stiffness, and weight efficiency are needed. Most commonly, sandwich Honeycomb core sandwich construction is usually utilized in panels that are employed in aircraft, automobiles, and satellites, which affect on the decreased consumption of power, higher speeds and increment in pay load [1,2]. The construction of a sandwich comprises of two thin facing layers disintegrated via a thick core. 
Accordingly, the strength properties of such panels are investigated via numerous researchers. The strength properties of the aluminum Honeycomb sandwich panels were investigated via. Kuldeep P. Toradmal et al. [3] conducted the analysis of the 3-point bending of the Honeycomb sandwich panels experimentally. In such investigation, GFRP was chosen as a face sheet material along with its metallic counterparts, like aluminum (Al) and stainless steel alloys. Polypropylene was utilized as a familiar material of core. Results showed a high value of ultimate load that occurred in the GFRPPolypropylene core. Rao K. Kantha et al. [4] provided a theoretical study on the strength of sandwich structure under a bending load with different face materials. Aluminum, titanium, and high tensile steel were used in this study. It was observed that the titanium alloy has a better property of sandwich structure. Doaa Fadhel Mohammed et al. [5] presented a numerical and experimental study of the bending behavior for a Honeycomb sandwich panel with various core forms (square, hexagonal and circular), each form has two kinds of facing: one of composite and the other of Al. Three point bending test was conducted in this research. Vidyasagar Matta et al. [6] used Taguchi design of experiment to study the flexural behavior of Al Honeycomb core sandwich structure experimentally. M.J. Jweeg et al. [ 7,8] achieved analytical and experimental investigations of composite plates under dynamic loading. Effect of the size of cell, sheet thickness and core height on the bending stress has been concluded. Same method was used by E. S. Arbintarso et al. [9] for investigating the bending stress of glass fiber reinforced polymer (GFRP) sandwich structure for lightweight vehicle. Also Abbas et al. [10] presented a theoretical and experimental prediction for optical cable properties and using vibration measurements technique for fault deduction. Three types of adhesives (The plastic steel epoxy resin, polyaminoamide-bisphenol-A resin, and thermosetting resin) used to adhesive the face and core. Hussain et al. [11] improved the mechanical propertied of sandwich panels by using glass fiber composite material for facing with aluminum Honeycomb core. A three-point bending load arrangement was conducted to examine the static and fatigue performance of Honeycomb sandwich panel. Experimental approach and numerical simulation have been concluded in this research.

Despite of the above-mentioned searches, the investigations on the strength of sandwich structures with Honeycomb core stay fairly bounded so far. The present study aims to fill the gap of the knowledge via giving an experimental and analytical investigation into the strength under 3-point bending to explore the effect of Honeycomb parameters (cell size, cell wall thickness and core high) on the peak load, maximum deflection, and energy absorption of sandwich structure with a Honeycomb core. Then, the RSM technique will be employed to get the optimum solution for the peak bending load, maximum deflection, and energy absorption.

\section{THEORETICAL INVESTIGATION}

In this section, the sandwich beams' elastic analysis in three-point bending was outlined for evaluating the stresses in the skin or the core and then loads of failure owing to the different mechanisms. A typical simply supported sandwich beam, with width (b), span (L), core height (c), cell size $\left(\mathrm{L}_{\mathrm{c}}\right)$ and cell wall thickness $\left(\mathrm{T}_{\mathrm{c}}\right)$ loaded in a three-point bending with a central load $(\mathrm{P})$ per unit width is illustrated in Figure 1.

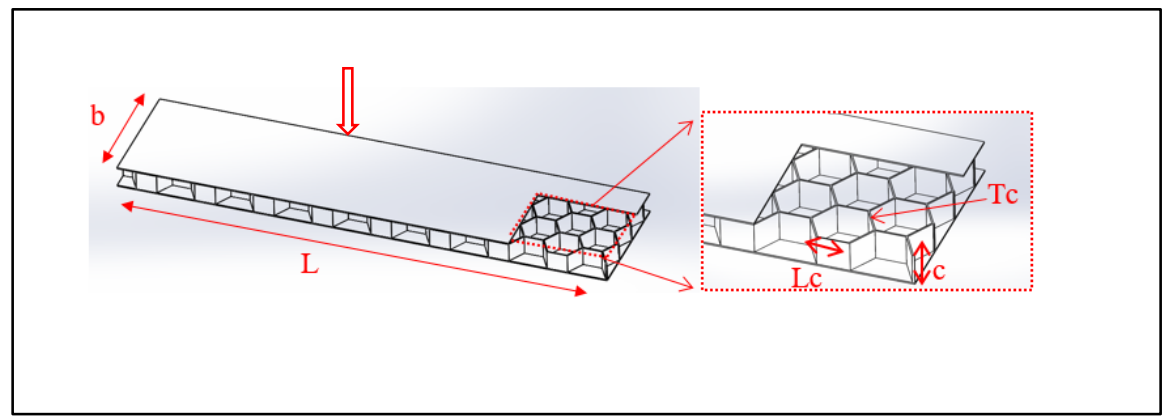

Figure 1: Simply supported honeycomb-core sandwich beam

It is assumed that the skins stays steadily bonded to the core, the beam bends in a cylindrical way without curvature in the yz-plane, and the cross sections stay plane and normal to the beam longitudinal axis. Then, the sandwich beam's flexural rigidity (D) is given via [12]: 


$$
D=\frac{E_{f} t_{f} b d^{3}}{2}
$$

Where, (d) represents the distance between the mid-planes of the bottom and upper skins. In three-point bending, the maximum bending moment $(\mathrm{M})$ is at the mid span, and the corresponding maximum stress $\left(\sigma_{f x}\right)$ of the skins is given via Allen[13]:

$$
\sigma_{f x}=\frac{P b L}{4}\left\lceil\frac{c+2 t_{f}}{2 I}+\frac{P L}{4} \frac{t_{f}}{2 I_{f}} \frac{1}{\theta}\right\rceil
$$

Where,

$$
\begin{gathered}
\Theta=\frac{L}{c}\left[\frac{G_{c}}{2 E_{f}} \frac{c}{t_{f}}\left(1+\frac{3 d^{2}}{t_{f}^{2}}\right)\right]^{0.5} \\
I=\frac{b t_{f}^{3}}{6}+\frac{b t_{f} d^{2}}{2}, I=\frac{b t_{f}^{3}}{6} \\
G_{c}=\frac{2 T c}{L c \cos \beta(1+\sin \beta)} G_{f}
\end{gathered}
$$

Where, $\left(\mathrm{G}_{\mathrm{c}}\right)$ is the core out-of-plane shear modulus of the core, $(\mathrm{Tc})$ is the cell wall thickness, (Lc) is the cell size, and ( $\beta$ ) is the cell angle, as shown in Figure 1 [14]. Also, (I) is the sandwich second moment of area with regard to its neutral axis, and $\left(\mathrm{I}_{\mathrm{f}}\right)$ is the face plates second moment of area with regard to their centroid axes. Eq.(3) reveals that $(\Theta)$ relies upon the relative stiffness of the core and skin. Eventually, Eq.(2) gives

$$
P=4 \sigma_{f x} \xi \frac{t_{f}}{L}
$$

Where

$$
\xi=\theta \frac{\frac{t_{f}{ }^{5}}{9}+\frac{t_{f}{ }^{3} d^{2}}{3}}{\frac{t_{f}{ }^{3} h(\theta-1)}{3}+\frac{t_{f}^{4}}{3}+t_{f}^{2} d^{2}}
$$

Shear stress changes through the core and face in a parabolic manner under three-point bending. When faces are thinner and too stiffer than the core, shear stress can be considered fixed in the core and a linear through the face. Neglecting the skins' contribution, the average shear stress in core is given via[15]:

$$
\tau_{c}=\frac{P}{2 d}
$$

\section{Skin failure}

Equation 2 gives a formula for the ultimate stress $\left(\sigma_{f x}\right)$ of skins. This can be utilized for predicting the failure of beam due to the modes of the skin failure which it are face yielding, face wrinkling and intra-cell dimpling, as demonstrated in Figure 2 [15]. The failure modes are explained as follows: 


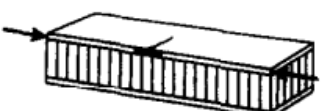

(a) Face yielding

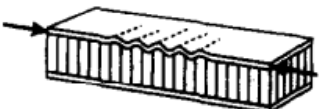

(b) Intra-cell dimpling

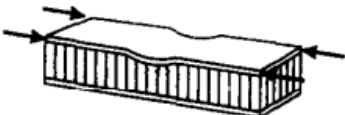

(c) Face wrinkling

Figure 2: Failure modes in the skins of sandwich beam[15]

\section{A. Face yielding}

The failure will take place in the upper skin owing to the yielding of face if the axial stress in both skins (Eq. (2) ) attains the in-plane strength $\left(\sigma_{f y}\right)$ of face material for the loading along the axis of beam.

$$
\sigma_{f x}=\sigma_{f y}
$$

B. Intra-cell dimpling

A sandwich having a honeycomb core perhaps fail via face buckling where it is unsupported by the honeycomb walls (Figure 2.b).

$$
\sigma_{f x}=\frac{2 E_{f}}{1-v_{f}}\left(\frac{2 t_{f}}{\alpha}\right)^{2}
$$

Where, $(\alpha)$ is the size of cell (i.e. the inscribed circle diameter) of honeycomb, and $\left(v_{f}\right)$ and $\left(E_{f}\right)$ are Poisson's ratio and modulus of elasticity of skin, respectively for the loading in axial direction. Equations (9) and (10) can be utilized for deriving the cell size value, over which there exists a transition from the yielding of face to the intra-cell buckling as [16]:

$$
\alpha=2 t_{f}\left(\frac{2 E_{f x}}{\left(1-v_{f x y}{ }^{2}\right) \sigma_{f y}}\right)^{0.5}
$$

C. Wrinkling of face

It's a mode of buckling of skin with a wavelength larger than the width of cell of a honeycomb as shown in Figure 3-c. via modeling the skin as a plate above an elastic base, Allen [13] gave the critical compressive stress $\left(\sigma_{f w}\right)$, which caused the upper skin wrinkling as:

$$
\begin{gathered}
\sigma_{f w}=\frac{3}{\left(12\left(3-v_{c x y}\right)^{2}\left(1+v_{c x y}\right)^{2}\right)^{-1 / 3}} E_{f x}{ }^{1 / 3} E_{3}{ }^{2 / 3} \\
E_{3}=\frac{2 E_{f}}{\cos \beta(1+\sin \beta)} \frac{T c}{L c} \\
v_{c x y}=\frac{(1+\sin \beta)^{2}(\sin \beta)^{2}}{12 L c^{3}(\cos \beta)^{2}\left[\frac{\cos \beta}{3}-\frac{1+\cos \beta}{8}\right]}
\end{gathered}
$$

Where, $\left(\mathrm{E}_{3}\right)$ is the out-of-plane Young's modulus, and $\left(v_{c x y}\right)$ is the out-of-plane Poisson's ratio of the core of honeycomb [14] .

\section{Failure of core}

The honeycomb sandwich structures that are loaded in bending can fail owing to the failure of core. The relevant modes of failure are the failure by shear or by the indentation via the local 
crushing in the nearness of loads, as elucidated in the Figure 3 [15-17]. The modes of failure in the core are explained as follows:

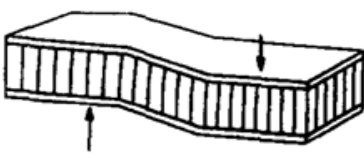

(a) Core shear

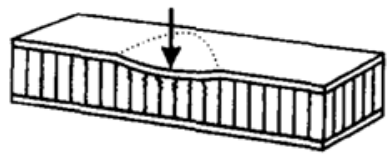

(b) Local indentation

Figure 3: : Modes of failure in the core [14]

A. Shear of core

The failure will take place if the shear stress $\left(\tau_{c}\right)$ is equal or exceeds the honeycomb yield strength in shear $\left(\tau_{\mathrm{cy}}\right)$. The failure of core is given by:

$$
\tau_{c}=\frac{V}{b t_{c}}=\tau_{c y}
$$

B. Indentation of core

It's merely a problem if the loads are too localized and can be prevented when one ensures that this load is spread above a minimum area that is at least

$$
A>\frac{P}{\sigma_{y c}}
$$

Where, $\left(\sigma_{\mathrm{yc}}\right)$ is the core compressive strength.

\section{Failure mode maps construction for the sandwich beams}

Sections (I) and (II) have described different failure mechanisms that take place with the honeycomb sandwich beam. So the load $(\mathrm{P})$ of failure can be manifested as a function of the properties of material and the parameters of beam $P=f\left(t_{f} / L, \rho_{c} / \rho s\right)$. For evaluating such function, the formulas for the core and skin stresses (Eq.(2) and Eq.(8))are substituted into different criteria of failure (Eqs.(9),(10), and(12))as depicted in section 2 to provide the critical loads as briefed in Table I.

TABLE I: Summary of failure load for each mode

\begin{tabular}{lcc}
\hline \hline Face yielding & $P=4 \sigma_{f y} \xi{ }^{t_{f}} / L$ \\
\hline $\begin{array}{c}\text { Intra-cell } \\
\text { dimpling }\end{array}$ & $P=\frac{8}{1-v_{f}{ }^{2}}\left(\frac{t_{f}}{\alpha}\right)^{2} E_{f} \times{ }^{t_{f}} / L \times \xi$ \\
$\begin{array}{c}\text { Face } \\
\text { wrinkling }\end{array}$ & $P=\frac{12 E_{f x}{ }^{1 / 3} E_{3}{ }^{2} / 3}{\left(12\left(3-v_{c x y}\right)^{2}\left(1+v_{c x y}\right)^{2}\right)^{-1 / 3}} \frac{t_{f}}{L} \xi\left(\frac{\rho_{c}}{\rho_{s}}\right)^{2 / 3}$ \\
\hline Core share & $P=3.4 E_{f} d\left(\frac{\rho_{c}}{\rho_{s}}\right)^{3}$ \\
\hline Indentation & $P=3.25 \sigma_{f y}{ }^{2}\left(\frac{\rho_{c}}{\rho_{s}}\right)^{5 / 3} \delta$ \\
\hline
\end{tabular}

A transition in the mechanism of failure will occur if two or several mechanisms possess the similar load. Such information can be viewed as diagram or map (failure-mode map). The highly significant transitions that one gets from equating the pairs of the equations of failure-mode include face yield-core shear, face yielding-face wrinkling, and face wrinkling-core shear. 
For face wrinkling and face yielding:

The face yielding/fracture takes place if

$$
\sigma_{f x}=\sigma_{f y}
$$

Thus, from Table I, the load $\mathrm{P}$ of failure is given via:

$$
P=4 \sigma_{f y} \xi^{t_{f}} / L
$$

The face wrinkling (local buckling) takes place if

$$
\sigma_{f x}=\sigma_{f w}
$$

Hence, from Table I the load P of failure can be stated as:

$$
P=\frac{12 E_{f x}{ }^{1 / 3} E_{3}{ }^{2 / 3}}{\left(12\left(3-v_{c x y}\right)^{2}\left(1+v_{c x y}\right)^{2}\right)^{-1 / 3}} \frac{t_{f}}{L} \xi\left(\frac{\rho_{c}}{\rho_{s}}\right)^{2 / 3}
$$

Equating Eq. (18) and Eq. (20), one obtains:

$$
4 \sigma_{f y} \xi^{t_{f}} / L=\frac{12 E_{f x}{ }^{1 / 3} E_{3}{ }^{2 / 3}}{\left(12\left(3-v_{c x y}\right)^{2}\left(1+v_{c x y}\right)^{2}\right)^{-1 / 3}} \frac{t_{f}}{L} \xi\left(\frac{\rho_{c}}{\rho_{s}}\right)^{2 / 3}
$$

Hence, the transition between face wrinkling and face yielding is given via this expression:

$$
\left(\frac{\rho_{c}}{\rho_{s}}\right)=\sqrt[3 / 2]{\frac{\sigma_{f y}\left(12\left(3-v_{c x y}\right)^{2}\left(1+v_{c x y}\right)^{2}\right)^{-1 / 3}}{3 E_{f x}{ }^{1 / 3} E_{3}{ }^{2 / 3}}}
$$

Similarly to (face yielding - core share) and (core share - face wrinkling)

$$
\left.\begin{array}{c}
\frac{\rho_{c}}{\rho_{s}}=\sqrt[1 / 3]{\frac{4 \sigma_{f y} \xi}{3.4 E_{f} d}}\left({ }^{\rho_{f}} / L\right)^{1 / 3} \\
\rho_{s}
\end{array}\right)=\sqrt[3 / 7]{\frac{12 E_{f x}{ }^{1 / 3} E_{3}{ }^{2 / 3} \xi}{3.4 E_{f} d\left(12\left(3-v_{c x y}\right)^{2}\left(1+v_{c x y}\right)^{2}\right)^{-1 / 3}}}\left(\frac{t_{f}}{L}\right)^{3 / 7}
$$

The transitions of failure modes in Eqs. (22), (23) and (24) are evinced in the failure mode map in Figure 4.

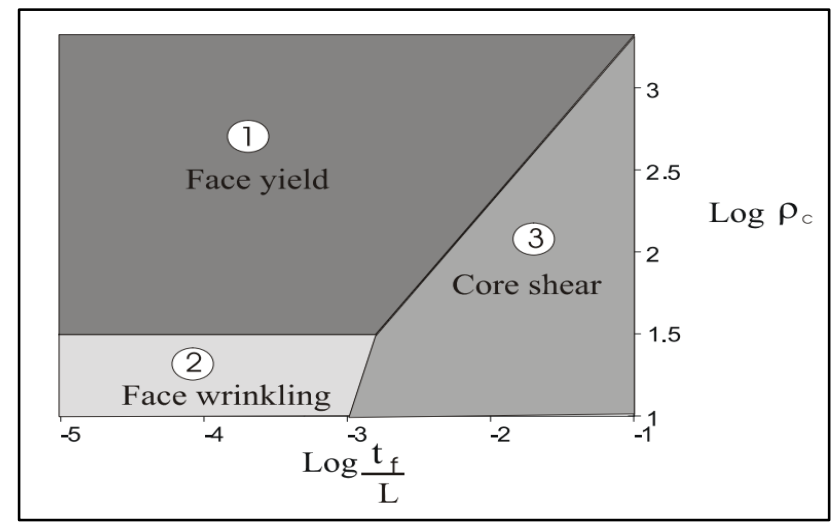

Figure 4: The failure mode map for an Aluminum sandwich beam in 3-point bending

\section{Deflection and energy absorption of sandwich beam}

Generally, the deflection $(\delta)$ of a simply-supported sandwich beam is the sum of the shear bending and the shear components [18-19] as: 


$$
\delta=\delta_{b}+\delta_{s}=\frac{p L^{3}}{48(E I)_{e q}}+\frac{p L}{4(A G)_{e q}}
$$

And the absorption of energy (Ea) can be determined via integrating the curve of loaddisplacement that depicts how much energy that the sandwich structure is able to absorb through a certain crushing distance

$$
\begin{gathered}
E_{a}=\int_{0}^{d} P(\delta) \partial \delta \\
E_{a}=\frac{\delta^{2}}{2\left(\frac{L^{3}}{48(E I)_{e q}}+\frac{L}{4(A G)_{e q}}\right)}
\end{gathered}
$$

\section{EXPERIMENTAL WORK}

\section{Material used and specimens preparation}

In this investigation, the face sheet and the core are made of aluminum alloy (AA3003) sheet. Table II lists the mechanical properties of this alloy via fixing the thickness of face sheet about $(0.5$ $\mathrm{mm}$ ), the thickness of cell wall is $0.5 \mathrm{~mm}$ and cell side length at $10 \mathrm{~mm}$. The specimen effective dimension was fixed at $(230 \mathrm{~mm} \times 45 \mathrm{~mm})$ in accordance with the ASTM standard C393 for the simply supported boundary condition as shown in Figure 5-a. The dimensions of sandwich specimens that were tested are given listed in Table III.

TABLE II: Mechanical prosperities of aluminum alloys (AA3003)

\begin{tabular}{ccc}
\hline \hline No & Specification & Value1 \\
\hline 1 & Elastic modules & $71 \mathrm{GPa}$ \\
\hline 2 & Poisson ratio & 0.33 \\
\hline 3 & Density & $2700 \mathrm{~kg} / \mathrm{m}^{3}$ \\
\hline 4 & Shear modules & $26 \mathrm{GPa}$ \\
\hline 5 & Yield stress & $280 \mathrm{MPa}$ \\
\hline
\end{tabular}

TABLE III: The dimensions of sandwich specimens

\begin{tabular}{cccccc}
\hline \hline $\begin{array}{c}\text { No. } \\
\text { specimen }\end{array}$ & $\begin{array}{c}\text { Material of } \\
\text { core and face }\end{array}$ & $\begin{array}{c}\text { Dimension of } \\
\text { specimen } \\
(\mathbf{m m})\end{array}$ & $\begin{array}{c}\text { Thickness of } \\
\text { face sheet } \\
(\mathbf{m m})\end{array}$ & $\begin{array}{c}\text { Height of } \\
\text { core height } \\
(\mathbf{m m})\end{array}$ & $\begin{array}{c}\text { Height of } \\
\text { specimen } \\
(\mathbf{m m})\end{array}$ \\
\hline $\mathbf{1}$ & $\mathrm{Al}$ & $230 \times 45$ & 0.5 & 10 & 11 \\
\hline $\mathbf{2}$ & $\mathrm{Al}$ & $230 \times 45$ & 0.5 & 15 & 16 \\
\hline $\mathbf{3}$ & $\mathrm{Al}$ & $230 \times 45$ & 0.5 & 20 & 21 \\
\hline $\mathbf{4}$ & $\mathrm{Al}$ & $230 \times 45$ & 0.5 & 25 & 26 \\
\hline
\end{tabular}

\section{Experimental setup}

A three point bending test was carried out to investigate the strength of sandwich beam. A twelve Honeycomb sandwich specimens were tested by three-point bending device which is (universal devise) as shown in Figure 5. Applying load through a roller of diameter $(5 \mathrm{~mm})$ in accordance with the ASTM standard C393 [20]. The cross-head speed is held constant and is chosen $(4 \mathrm{~mm} / \mathrm{sec})$. The displacement of the central loading point was monitored on a computer. 


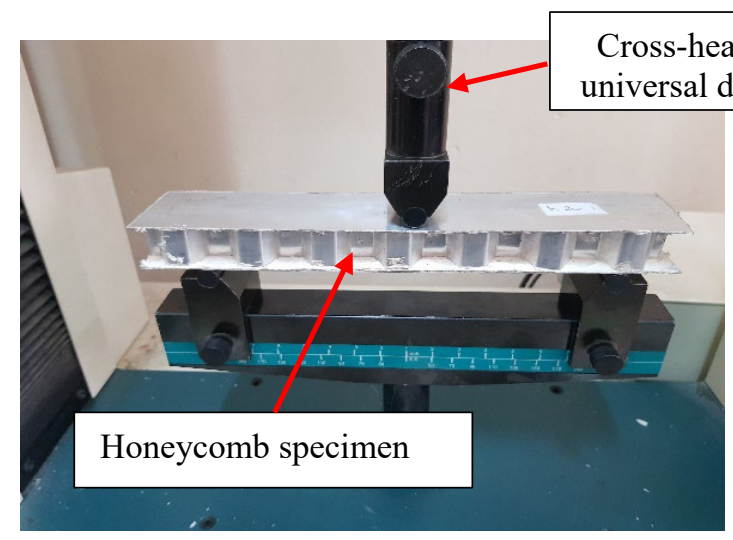

a-honeycomb specimen and experimental setup

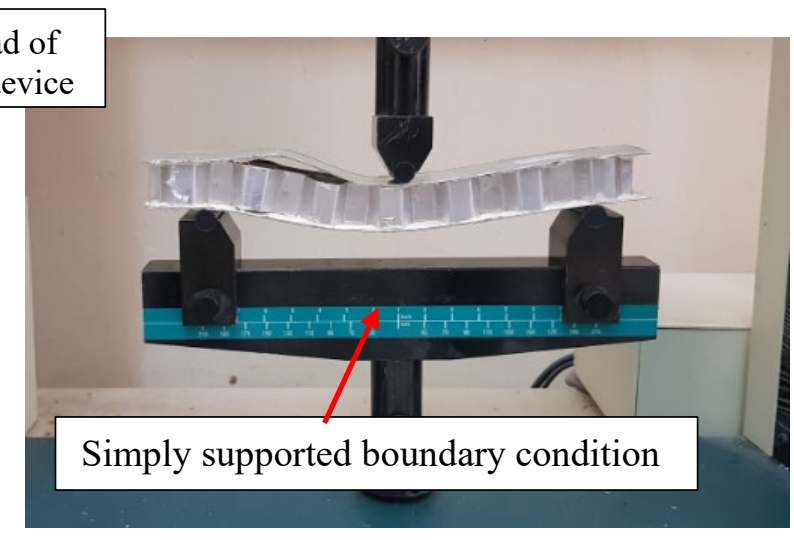

b- failure mode of specimen

Figure 5 : Three point bending test

\section{Experimental results and comparison study}

The experiential results of three point bending test for sandwich specimens with various height $(10,15,20$ and 25) has illustrated in Figures 6-9 respectively. The experimental results presented the load- deflection curve. For the purpose of comparison, the theoretical valve of maximum bending load and maximum bending deflection calculate by employing Eq. (6) and Eq. (35) for the same experimental specimens as shown in Tables IV and V respectively. From these Tables, it can be noted that the error ratio not exceeded $15 \%$ for maximum bending load and $12 \%$ for and maximum deflection. From the logical reasons for this error ratio are the existence the adhesive material between the faces and Honeycomb core in sandwich specimen while the theoretical solution built on assumption the perfect contact between the faces and core, probability of interfacing the modes of failure in practical test (see failure mode maps), device accuracy, experience of lab guy that performed the test and the industrial defects, all these reasons cause the error ratio.

TABLE IV:Theoretical and experimental value of maximum bending load

\begin{tabular}{cccc}
\hline \hline \multirow{2}{*}{$\mathbf{h}$} & \multicolumn{3}{c}{$\mathbf{P}_{\max }(\mathbf{N})$} \\
\cline { 2 - 4 } & Theoretical & Experimental & Error ratio \\
\hline 0.01 & 850.781 & 751.2 & 11.7 \\
\hline 0.015 & 1166.644 & 1073.313 & 8.0 \\
\hline 0.02 & 1517.156 & 1289.582 & 15.0 \\
\hline 0.025 & 1856.755 & 1674.97 & 9.7 \\
\hline
\end{tabular}

TABLE V: Theoretical and experimental value of maximum bending deflection

\begin{tabular}{cccc}
\hline \hline \multirow{2}{*}{$\mathbf{h}$} & \multicolumn{3}{c}{$\boldsymbol{\delta}$ max } \\
\cline { 2 - 4 } & Theoretical & Experimental & error ratio \\
\hline 0.01 & 2.479 & 2.169 & 12.53 \\
\hline 0.015 & 1.671 & 1.521 & 9.003 \\
\hline 0.02 & 1.255 & 1.1303 & 10.002 \\
\hline 0.025 & 1.003 & 0.96 & 4.3336 \\
\hline
\end{tabular}




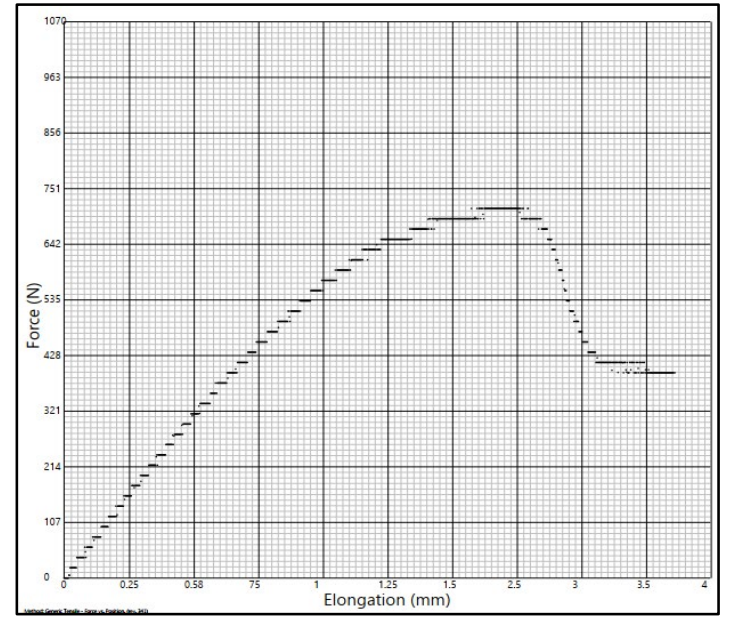

Figure 6: Load- deflection curve of specimen 1

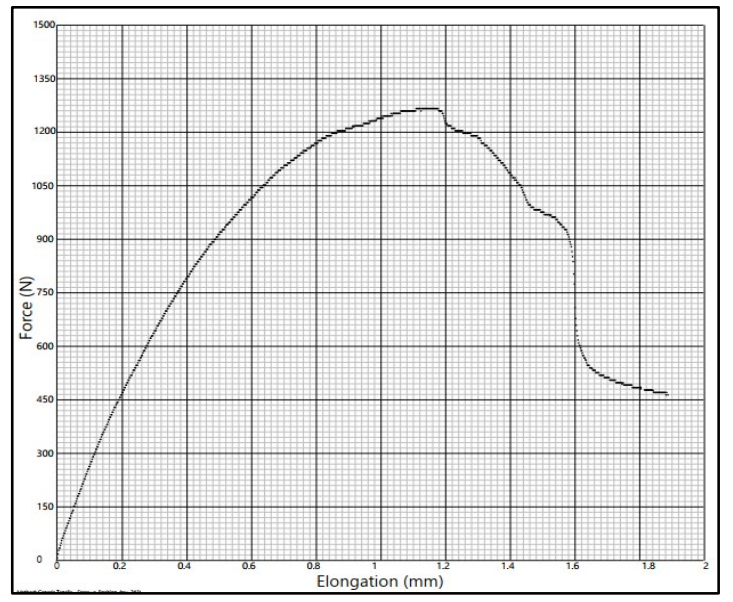

Figure 8: Load- deflection curve of specimen 3

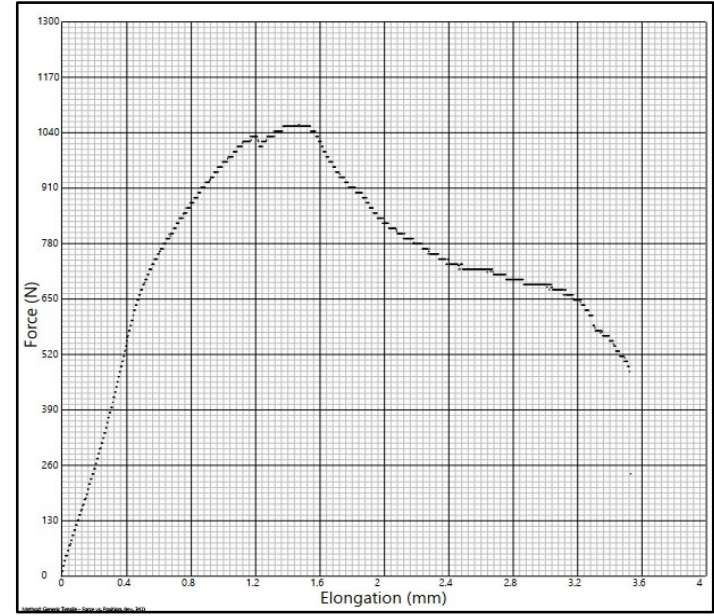

Figure 7: Load- deflection curve of specimen 2

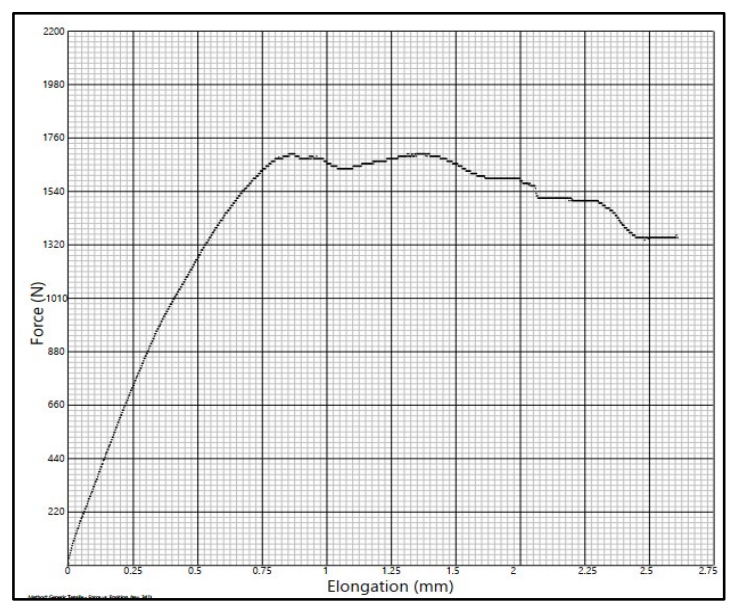

Figure 9: Load- deflection curve of specimen 4

\section{RESULTS AND DISCUSSION}

For investigating the Honeycomb parameters effects upon the static behavior of sandwich beam, theoretical solutions are used here. Honeycomb parameters and its variation were listed in Table VI. Failure modes maps (Figure 4) were used to identify the failure load Equation (Table I). The effected length and width of sandwich beam are $(\mathrm{L}=210 \mathrm{~mm})$ and $(\mathrm{b}=35 \mathrm{~mm})$, respectively.

TABLE VI:Dimension of honeycomb

\begin{tabular}{cc}
\hline \hline Parameter & Value (mm) \\
\hline Core high (c) & $10,15,20$ and 25 \\
\hline Cell size (Lc) & $10,15,20$ and 25 \\
\hline Cell wall thickness (Tc) & $0.3,0.5,0.7$ and 1 \\
\hline
\end{tabular}

\section{Honeycomb parameters effect}

The results evaluated included the peak bending load, energy absorption and maximum deflection of the honeycomb sandwich beam with various cell size, cell wall thickness and core high. Figure 10-a shows 3D surface plot of the peak bending load variation with core high for different values of cell size at cell wall thickness equal to 0.515 . The sandwich structure bending stiffness was highly affected via the core height of Honeycomb. This is due to the fact that sandwich beam second moment of inertia can be highly influenced via the core high of Honeycomb. Therefore, the peak load of bending is increasing with the increase of core high and cell wall thickness. This is in consistent 
with the work presented in [19], which achieved an experimental study on the failure mechanics of sandwich panel under three-point bending. On the other hand, the increasing of cell size leads to a decrease in the core density, which reduces the Young's modulus and shear rigidity of Honeycomb core. As result, the peak bending load is reduced as illustrated in Figure 10-c. Figure 11-a reveals the variation of the maximum deflection with core high for different values of size cell at cell wall thickness equal to 0.515. An increase in the core high and cell size results a reduction in the maximum deflection value, while the increase in the cell wall thickness leads to an increase in the maximum deflection as illustrated in Figure 11-c . To understand the influence of Honeycomb parameters on the energy absorption, Figure 12-a shows the variation of the energy absorption with core high for different values of size cell at thickness of cell wall equal to $0.515 \mathrm{~mm}$. An increase in the core height and cell size results a reduction in the value of the energy absorption, while the increase in the cell wall thickness leads to an increase in the energy absorption.

\section{Optimization Solution}

The main goal of this study is to find the optimal parameters that give the maximum bending load, minimum deflection and maximum energy absorption, thus avoiding the failure of this structure due to static load. RSM was utilized to achieve the analytical optimization and to obtain the optimum factors. For establishing a new predicted model, an objective function, which is named "Desirability" to allow for a proper combining the goals, was estimated. This desirability must be maximized via the theoretical optimization, and its range is from 0 to 1[21]. Figure 13 illustrates the optimum parameters for peak bending load, deflection and energy absorption, respectively.

\section{CONCLUSIONS}

1) According to RMS, the optimal solution for maximum bending load, minimum deflection and maximum energy absorption were found at $25 \mathrm{~mm}$ core height, $10 \mathrm{~mm}$ size of cell and $1 \mathrm{~mm}$ thickness of cell wall. Where, the optimal value of maximum bending load, minimum deflection and maximum energy absorption were $1975.3415 \mathrm{~N}, 1.0402 \mathrm{~mm}$ and $1.0229 \mathrm{~J}$, respectively.

2) Peak bending load is directly proportional with the cell wall thickness and core height but inversely proportional with cell size.

3) The increasing of cell size and core high leads to deceasing the defection and energy absorption, but the increasing in cell wall thickness results an increase in the defection and energy absorption.

4) Core height has the largest effect on the crashworthiness properties of sandwich panels.

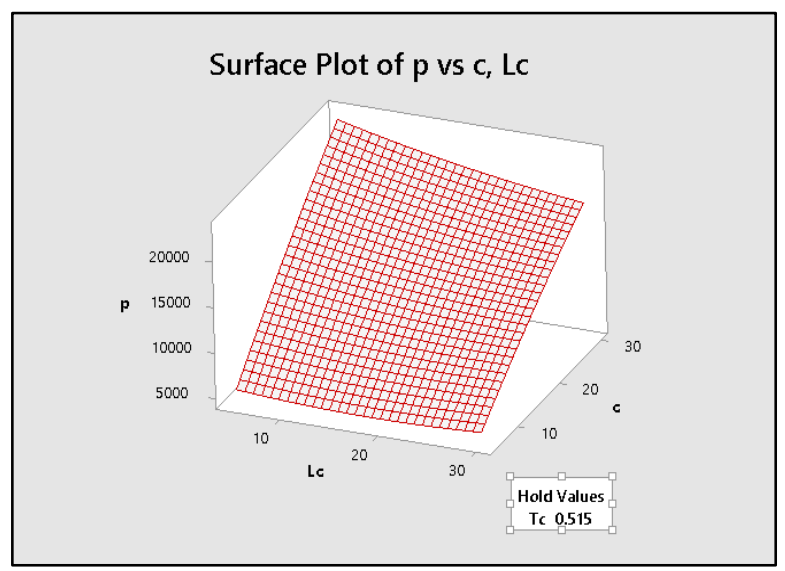

a. $\mathrm{P}$ as a function of cell size and core high

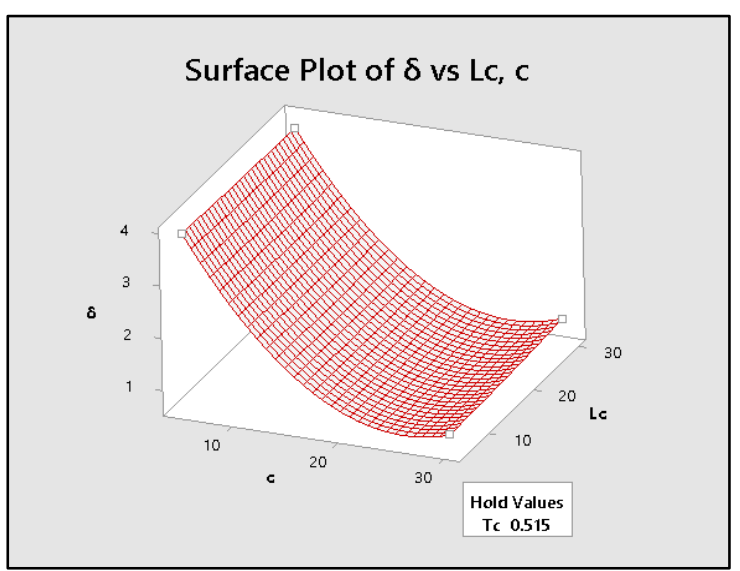

a. $\delta$ as a function of cell size and core high 


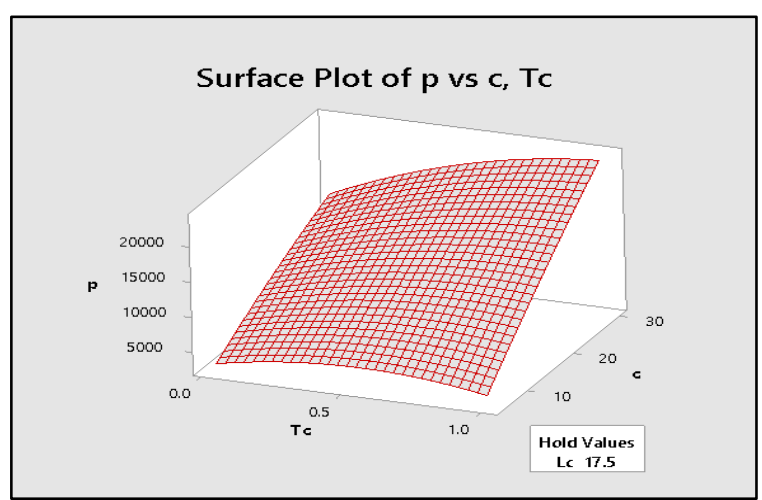

b. P as a function of cell wall thickness and core high

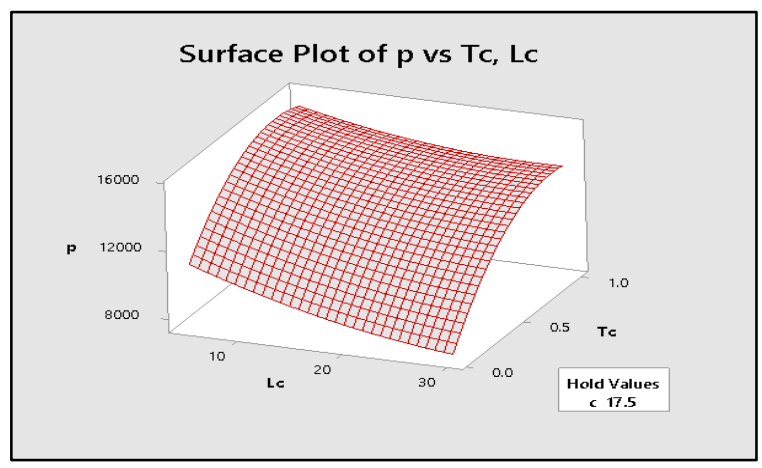

c. $P$ as a function of cell size and cell wall thickness

Figure 10: 3D graph of peak bending load as A function of honeycomb parameter

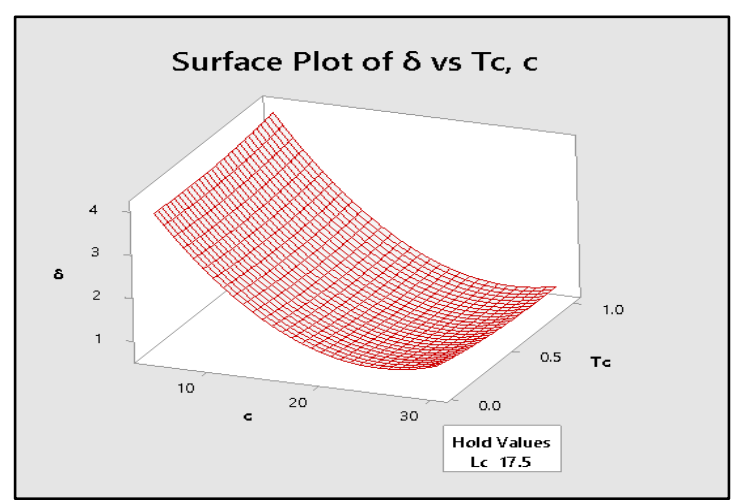

b. $\delta$ as a function of cell wall thickness and core high

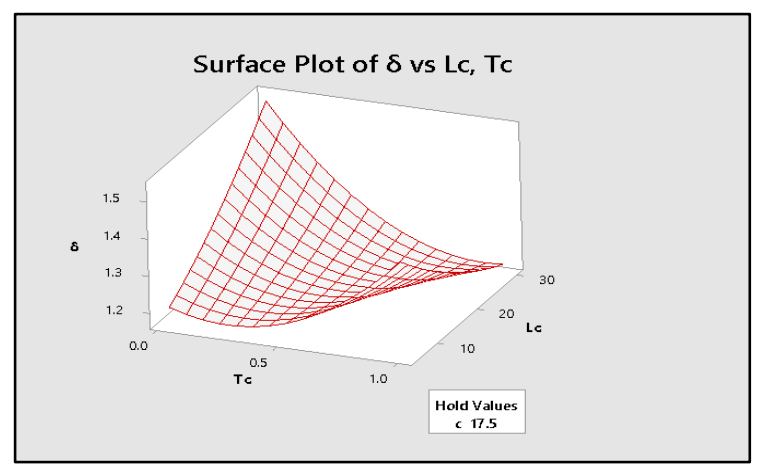

c. $\delta$ as a function of the cell size and the cell wall thickness

Figure 11: 3D graph of $\delta_{\max }$ as a function of honeycomb parameter

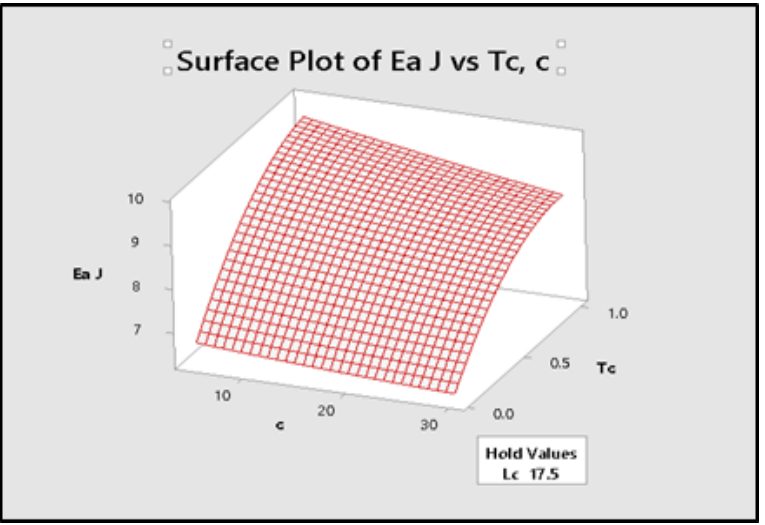

a. $E_{a}$ as a function of cell wall thickness and core high

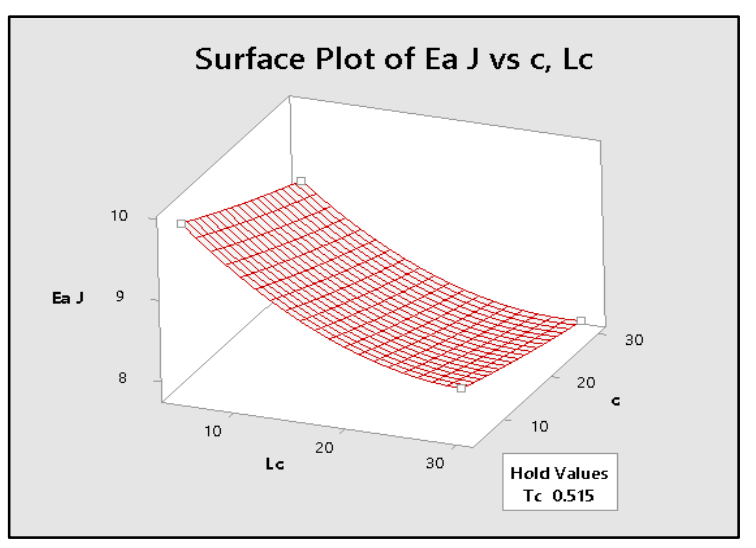

b. Ea as a function of cell size and core high 


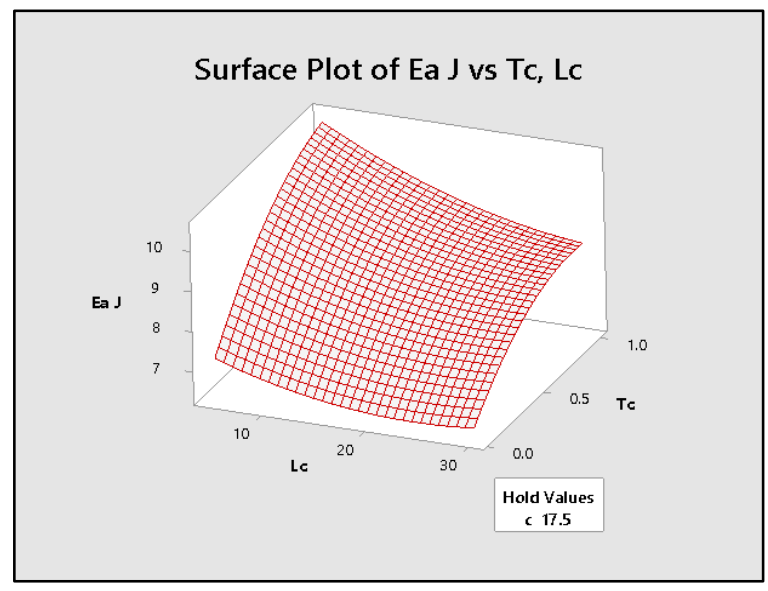

c. Ea as a function of the cell size and the cell wall thickness

Figure 12: 3D graph of Ea as a function of honeycomb parameter

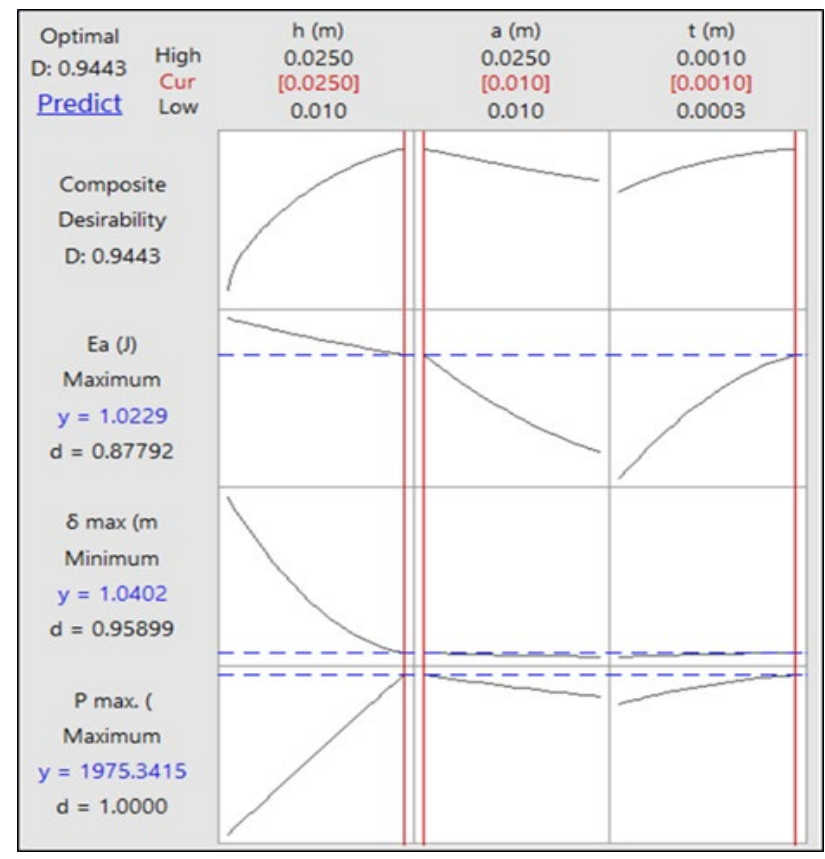

Figure 13: Optimum parameters

Nomenclatures

$\mathrm{b}$

$\mathrm{c}$

$\mathrm{D}$

d

$\mathrm{E}_{3}$

$\mathrm{E}_{\mathrm{a}}$

$\mathrm{E}_{\mathrm{f}}$

$\mathrm{G}_{\mathrm{c}}$

I

$\mathrm{I}_{\mathrm{f}}$

L
Width of sandwich plate $(\mathrm{m})$

Core height $(\mathrm{m})$

Flexural rigidity $\left(\mathrm{Pa} \mathrm{m}^{4}\right)$

Distance between the mid-planes of the bottom and upper skins (m)

The out-of-plane Young's modulus of the core of honeycomb

Eenergy absorption of sandwich beam

Modulus of elasticity of skin

The core out-of-plane shear modulus of the core

The sandwich second moment of area

The face plates second moment of area

Length of honeycomb sandwich (mm) 


$\begin{array}{ll}\mathrm{L}_{\mathrm{c}} & \text { Cell size }(\mathrm{mm}) \\ \mathrm{M} & \text { The maximum bending moment at the mid span (N.m) } \\ \mathrm{P} & \text { Central load of three-point bending }(\mathrm{N}) \\ \mathrm{T}_{\mathrm{c}} & \text { Cell wall thickness (m) } \\ \text { Greek Symbols } & \\ \alpha & \text { the size of cell (mm) } \\ \beta & \text { the cell angle (degree) } \\ \delta & \text { the deflection (m) } \\ v_{\mathrm{f}} & \text { Poisson's ratio of elasticity of skin } \\ \sigma_{\mathrm{fw}} & \text { critical compressive stress which caused the upper skin wrinkling } \\ \sigma_{\mathrm{fx}} & \left(\mathrm{N} / \mathrm{mm}^{2}\right) \\ \sigma_{\mathrm{fy}} & \text { maximum stress of the skins }\left(\mathrm{N} / \mathrm{mm}^{2}\right) \\ \sigma_{\mathrm{yc}} & \text { the in-plane strength of face material }\left(\mathrm{N} / \mathrm{mm}^{2}\right) \\ \tau_{\mathrm{c}} & \text { the core compressive strength }\left(\mathrm{N} / \mathrm{mm}^{2}\right) \\ \tau_{\mathrm{cy}} & \text { shear stress of honeycomb core }\left(\mathrm{N} / \mathrm{mm}^{2}\right)\end{array}$

\section{REFERENCES}

[1] M. J. Jweeg, A suggested analytical solution for vibration of honeycombs sandwich combined plate structure, Int. J. Mech. Mechatron. Eng., 16(2016) 1-9.

[2] M. A. Al-Shammari and M. AL-Waily, Analytical investigation of buckling behavior of honeycombs sandwich combined plate structure, Int. J. Mech. Eng., 8(2018) 803-818. http://dx.doi.org/10.24247/ijmperdaug201883

[3] K. P. Toradmal, P. M. Waghmare, and S. B. Sollapur, Three-point bending analysis of honeycomb sandwich panels : experimental approach, Int. J. Eng. Technol., 3(2017) 3-7.

[4] K. K. Rao, K. J. Rao, A. G. Sarwade, and M. S. Chandra, Strength analysis on honeycomb sandwich panels of different materials, Int. J. Eng. Res. Appl., 2(2012) 365-374.

[5] D. F. Mohammed, H. A. Ameen, and K. M. Mashloosh, Experimental and numerical study of bending behavior for honeycomb sandwich panel with different core configuration, IQJMME., 16(2016) 315-328.

[6] V. Matta, J. Suresh Kumar, D. Venkataraviteja, and G. B. K. Reddy, Flexural behavior of aluminum honeycomb core sandwich structure, IOP Conf. Ser. Mater. Sci. Eng., 197(2017). http://dx.doi.org/10.1088/1757-899X/197/1/012046

[7] M.J. Jweeg and M.L. Al-Waily, Analytical and numerical Investigation for dynamic response of composite plates under dynamic loading with the influence of carbon-wall tube nanomaterials, Int. J. Mech. Mechatron. Eng., 18(2018) 6 .

[8] M.J.Jweeg and M.L. Al-Waily, Analytical investigation of time dependent tensional loading of stiffened and unstiffened composite laminated plates, Int. J. Mech. Mechatron. Eng., 3(2018) 83-96.

[9] E. S. Arbintarso et al., The bending stress on GFRP honeycomb sandwich panel structure for a chassis lightweight vehicle, SAICOET., Indonesia, 2018. http://dx.doi.org/10.1088/1757-899X/506/1/012050

[10] H.J. Abbas, M.L. Al-Wailiy, M.J. Jweeg, and A.A. Diwan, Theoretical prediction of fiber optical cable for fault detection and identification, J. Eng. Appl. Sci., 14(2019) 430-438. https://dx.doi.org/10.36478/jeasci.2019.430.438

[11] M. Hussain, R. Khan, and N. Abbas, Experimental and computational studies on honeycomb sandwich structures under static and fatigue bending load, J. King Saud Univ. Sci., 31(2019) 222-229. https://doi.org/10.1016/j.jksus.2018.05.012 
[12] T. C. Triantafillou and L. J. Gibson, Failure mode maps for foam core sandwich beams Materials Science and Engineering, 95(1987) 37-53. https://doi.org/10.1016/0025-5416(87)90496-4

[13] H. G. Allen, Analysis and design of structural sandwich panels, First edition, pergamon press, New York, 1969.

[14] E. Nast, on honeycomb-type core moduli, American Institute of Aeronautics and Astronautics, AIAA-971178, Germany, 1997.

[15] A. Petras and M. P. F. Sutcliffe, Failure mode maps for honeycomb sandwich panels, Composite Structures, 44(1999) 237-252. https://doi.org/10.1016/S0263-8223(98)00123-8

[16] L. A. Carlsson and G. A. Kardomateas, Structural and failure mechanics of sandwich composites, Springer, New York, 2011.

[17] M. Sadighi, A. A. Dehkordi, and R. Khodambashi, A Theoretical and experimental study of failure maps of sandwich beams with composite skins and honeycomb, AUT J. Model. Simul., 42 (2010) 37-47.

[18] D. Lukkassen and A. Meidell, Advanced materials and structures and their fabrication processes, Book manuscript, Narvik University College, HiN , 2007.

[19] G. Sun, X. Huo, D. Chen, and Q. Li, Experimental and numerical study on honeycomb sandwich panels under bending and in-panel compression, Mater. Des., 133 (2017) 154-168. https://doi.org/10.1016/j.matdes.2017.07.057

[20] ASTM Standards, Standard Test Method for Flexural Properties of Sandwich Constructions, C 393 - 00 , 2005 .

[21] S. E. Sadiq, S. H. Bakhy, M. J. Jweeg, Effects of spot welding parameters on the shear characteristics of aluminum honeycomb core sandwich panels in aircraft structure, Test Eng. Manag., 83(2020) 7244 - 7255. 